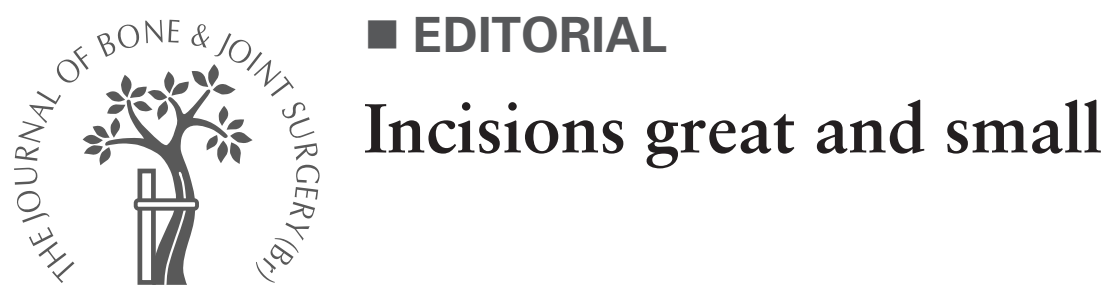

\begin{abstract}
A. K. Lilikakis, R. N. Villar

From the BUPA Cambridge Lea Hospital, Cambridge, England
\end{abstract}

A. K. Lilikakis, MD, Orthopaedic Surgeon R. N. Villar, MS, FRCS, Consultant Orthopaedic Surgeon Cambridge Hip and Knee Unit, BUPA Cambridge Lea Hospital, Impington, Cambridge CB4 9EL, UK.

Correspondence should be sent to Mr R. Villar.

(C)2004 British Editorial

Society of Bone and

Joint Surgery

doi:10.1302/0301-620X.86B6.

$15288 \$ 2.00$

$J$ Bone Joint Surg [Br]

2004;86-B:781-2.
The concept of minimally invasive surgery is perhaps the most important revolution in surgical technique in recent times and is now applied to most surgical specialties. In general surgery, for example, laparoscopic cholecystectomy was the first procedure to be widely adopted. Its importance was more the cultural change it engendered than the success of the operation. Other laparoscopic procedures such as appendectomy, adrenalectomy or splenectomy are now well documented, while others are still being assessed. ${ }^{1-6}$ Mini-incision cardiovascular surgery forms an increasing percentage of valvular or vascular procedures in appropriately selected patients. ${ }^{7-10}$ In orthopaedic surgery arthroscopy is now firmly established, mini-incision knee replacement widely publicised ${ }^{11}$ and now minimal incision total hip replacement has joined the field. Its development may be driven by a desire to reduce costs and morbidity ${ }^{12,13}$ and influenced by a news-hungry media, but does it truly advance patient care? ${ }^{14-17}$

Minimal access orthopaedic surgery can be subdivided into endoscopic (arthroscopic) or minimal incision surgery. Arthroscopic surgery has evolved significantly during the last two decades and can now be applied to almost every synovial joint of the body with proven success. ${ }^{18}$ Some procedures have become the standard means of diagnosis and treatment, ${ }^{19-21}$ while others have only recently been introduced. ${ }^{22}$ The definition of minimally invasive hip surgery is still uncertain although it is clearly distinct from arthroscopic surgery of the hip. Some publications refer to total hip replacement with the use of navigation through a 10 to $15 \mathrm{~cm}$ incision as minimally invasive, ${ }^{23}$ while others suggest that a $5 \mathrm{~cm}$ incision is appropriate. ${ }^{24}$ A single-incision posterior approach, ${ }^{23-26}$ a mini-anterior ${ }^{27}$ or a two-incision, fluoroscopically-controlled approach ${ }^{28}$ have also been proposed. None of these procedures reduces the amount of surgical trauma to bone but are associated with less handling of soft tissue. Specialised instrumentation may be required for which a steep learning curve is a feature. ${ }^{23-25,27,28}$

The main advantages to be expected from these minimally invasive techniques are less pain, earlier mobility, a reduced requirement for transfusion and a shorter length of stay in hospital. ${ }^{26,29,30}$ Unfortunately, existing publications refer to either very small series or have too short periods of follow-up. Chimento and Sculco, ${ }^{31}$ Waldman ${ }^{25,26}$ and Sherry et al ${ }^{24}$ have each published their initial experiences in groups of non-obese patients but without control groups. Wenz et $\mathrm{al}^{29}$ in a retrospective, non-randomised study, compared the mini-posterior with a conventional lateral approach. They reported significant earlier mobility, decreased transfusion requirements, less transfer assistance and a more favourable condition of the patient on discharge. There was no difference in the length of stay in hospital. DiGioia et $\mathrm{al}^{23}$ reported significantly better scores for pain and function in the first six months after operation in patients with a $\mathrm{BMI}<30$ with their computer-assisted technique. No difference was found after one year or in the length of stay in hospital. Similarly, Chimento et $\mathrm{al}^{30}$ described a decrease in blood loss and a quicker return to normal gait in patients with a $\mathrm{BMI}<30$. No increase in the rate of complications was found two years after surgery.

Currently, the literature lacks precise data on the duration of the operations for a minimally invasive total hip replacement or information about the learning curve, cost effectiveness, patient satisfaction or the longterm results. Hearsay suggests that minimally invasive techniques may take considerably longer to perform than the more traditional procedures and that the rate of intra-operative or long-term complications may be higher. Comparative, prospective, blinded studies do not yet exist. Orthopaedic surgeons worldwide appear to be embracing this new technique, but it is still unproven and has recognised problems such as malpositioning of the cup. 
However, it is becoming widely used and tightly bound with new protocols for anaesthesia, post-operative analgesia and rehabilitation. ${ }^{32}$ Despite this, concern has already been expressed about the method by Sculco, ${ }^{33}$ one of its pioneers, who has stated that "It must be emphasized that a prosthetic arthroplasty is not a minimally invasive procedure, regardless of the approach....Cosmesis should never be substituted for an excellent arthroplasty outcome".

The publicity given by the media, combined with a public that is eager for novelty, appear to make a great impact on a surgeon's choice. Surely this is questionable? Peerreviewed data should be the criteria before changing a method of treatment, with the focus of attention being to maximise the benefit to a patient rather than to display virtuosity. A rational approach is needed when dealing with new procedures, so that both surgeons and patients benefit. Many surgical innovations have been introduced in the past and accepted widely initially only to disappear ignominiously some years later. Let us hope, for the sake of our patients, that minimal incision total hip replacement is an exception.

\section{A. Lilikakis}

R. Villar

\section{References}

1. Darzi A, Mackay S. Recent advances in minimal access surgery. BMJ 2002;324: $31-4$

2. Sub HH. A minimally invasive technique of appendectomy using a minimal skin incision and laparoscopic instruments. Surg Laparosc Endosc 1998;8:149-52.

3. Rosen M, Brody F, Walsh RM, et al. Outcome of laparoscopic splenectomy based on hematologic indication. Surg Endosc 2002;16:272-9.

4. Bageacu S, Blanc P, Breton C, et al. Laparoscopic repair of incisional hernia: a retrospective study of 159 patients. Surg Endosc 2002;16:345-8.

5. Mourad M, Saab N, Malaise J, et al. Minimally invasive video-assisted approach for partial and total thyroidectomy: initial experience. Surg Endosc 2001;15:1108-11.

6. Perry KT, Freedland SJ, Hu JC, et al. Quality of life, pain and return to normal activities following laparoscopic donor nephrectomy versus open mini-incision donor nephrectomy. J Uro/ 2003;169:2018-21.

7. Richens D, Jutley RS, Baker M, Shajar M. Minimal access mitral valve replacement. J R Coll Surg Edinb 2002;47:676-80.

8. Cremer J, Boning A, Fraund S. Minimally invasive coronary surgery. Herz 2002;27: 402-6.

9. Turnipseed WD, Carr SC, Tefera G, Acher CW, Hoch JR. Minimal incision aortic surgery. J Vasc Surg 2001;34:47-53.

10. Cerveira JJ, Halpern VJ, Faust G, Cohen JR. Minimal incision abdominal aortic aneurysm repair. J Vasc Surg 1999;30:977-84.
11. Bonutti PM, Neal DJ, Kester MA. Minimal incision total knee arthroplasty using the suspended leg technique. Orthop 2003;26:899-903.

12. Schafer M, Krahenbuhl L, Farhadi J, Buchler MW. Cholelothiasis: Iaparoscopy or laparotomy? Ther Umsch 1998;55:110-15.

13. Cohn LH, Adams DH, Couper GS, et al. Minimally invasive cardiac valve surgery improves patient satisfaction while reducing costs of cardiac valve replacement and repair. Ann Surg 1997;226:421-6

14. Ehrlich W, Skwara W, Klovekorn W, Roth M, Bauer EP. Do patients want minimally invasive aortic valve replacement? Eur J Cardiothorac Surg 2000;17:714-17.

15. Passlick B, Born C, Mandelkow H, Sienel W, Thetter O. Long-term complaints after minimal invasive thoracic surgery operations and thoracotomy. Chirurg 2001;72: 934-8.

16. Rogers DA, Elstein AS, Bordage G. Improving continuing medical education for surgical techniques: applying the lessons learned in the first decade of minimal access surgery. Ann Surg 2001;233:159-66.

17. Calvert NW, Troy GP, Johnson AG. Laparoscopic cholecystectomy: a good buy? A cost comparison with small-incision (mini) cholecystetomy. Eur J Surg 2000;166: 782-6.

18. Villar RN. Arthroscopy. BMJ 1994;308:51-3.

19. Howell JR, Handoll HH. Surgical treatment for meniscal injuries of the knee in adults. (Cochrane Review). In: The Cochrane Library, Issue 1, 2004. Chichester, UK: John Wiley \& Sons, Ltd

20. Schulte KR, Chu ET, Fu FJH. Arthroscopic posterior cruciate ligament reconstruction. Clin Sports Med 1997;16:145-56.

21. Veltri DM. Arthroscopic anterior cruciate ligament reconstruction. Clin Sports Med 1997:16:123-44

22. Yamaguchi K, Ball CM, Galatz LM. Arthroscopic rotator cuff repair: transition from mini-open to all-arthroscopic. Clin Orthop 2001;390:83-94

23. Di Giola AM 3rd, Plakseychuk AY, Levison TJ, Jaramaz B. Mini-incision technique for total hip arthroplasty with navigation. J Arthroplasty 2003;18:123-8.

24. Sherry E, Egan M, Warnke PH, Henderson A, Eslick GD. Minimal invasive surgery for hip replacement: a new technique using the NILNAV hip system. ANZ Surg 2003;73:157-61.

25. Waldman BJ. Advancements in minimally invasive total hip arthroplasty. Orthop 2003;26(Suppl 8):833-6.

26. Waldman BJ. Minimally invasive total hip replacement and perioperative management: early experience. J South Orthop Assoc 2002;11:213-17.

27. Kennon RE, Keggi JM, Wetmore RS, Zatorski LE, Huo MH, Keggi KJ. Total hip arthroplasty through a minimally invasive anterior surgical approoach. J Bone Joint Surg [Am] 2003;85-A:39-48.

28. Duwelius PJ, Berger RA, Hartzband MA, Mears DC. Two-incision minimally invasive total hip arthroplasty: operative technique and early results from four centres. J Bone Joint Surg [Am] 2003;85-A:2240-2

29. Wenz JF, Gurkan I, Jibodh SR. Mini-incision total hip arthroplasty: a comparative assessment of perioperative outcomes. Orthop 2002;25:1031-43.

30. Chimento GF, Pavone V, Sharrock NE, et al. Minimal invasive total hip arthroplasty: a prospective randomised study: paper presented at 70th Annual Meeting of the American Academy of Orthopaedic Surgeons. New Orleans 2003.

31. Chimento GF, Sculco TP. Minimally invasive total hip arthroplasty. Operative Techniques in Orthopaedics 2001;11:270-3.

32. Lieberman J. Ethics of introduction of new operative procedures and technology. J Bone Joint Surg [Am] 2003;85-A:2243-6.

33. Sculco TP. Is smaller necessarily better? Am J Orthop 2003;32:169 